\title{
MEMBUMIKAN LESSON STUDY DALAM MENINGKATKAN KEMAMPUAN MENGAJAR BERBASIS STEM BAGI GURU MATEMATIKA SMK NEGERI 1 SINGKEP KABUPATEN LINGGA
}

\author{
Samsul Hadi \\ SMK Negeri 1 Singkep, Kepulauan Riau, Indonesia \\ Email: hadisamsul0869@gmail.com
}

\section{Abstract}

This study aims to apply lesson studies to improve STEM-based teaching skills for teachers of SMK Negeri 1 Singkep. The application of lesson studies is expected to be useful in improving teaching skills after the implementation and culture of lesson studies among mathematics teachers. In this study, the researcher as the principal with a mathematics teacher background implemented learning through workshops as a practice of implementing and understanding teaching teachers. With STEM-based learning, it is hoped that teachers can carry out discussions in planning lessons, implement teacher learning models in teaching and be able to reflect on learning. The research used school action based on Kemmis \& Taggart which consisted of 2 cycles starting with planning, acting, observing and reflecting. As research subjects are teachers of SMK Negeri 1 Singkep which consists of 28 teachers. From the results of this study, it was found that through the application of this method, (1) teachers can improve STEM-based teaching skills, (2) teachers can improve skills in making observations, and (3) teachers can increase knowledge in terms of adding insight into learning methods in class. Based on the results of data analysis, it shows that this method is effective for improving the teaching ability of STEM-based teachers, in the first cycle the teacher's average ability was 70.82 and increased to 78.88 in the second cycle, an increase of 8.06 was quite significant.

Keywords: lesson study; STEM; Mathematics

\section{Abstrak}

Penelitian ini bertujuan untuk menerapkan lesson study dalam meningkatkan kemampuan mengajar berbasis STEM bagi guru SMK Negeri 1 Singkep. Penerapan lesson study diharapkan bermanfaat dalam meningkatkan kemampuan mengajar setelah diterapkan dan dibudayakan lesson study di kalangan guru matematika. Dalam penelitian ini, peneliti selaku kepala sekolah berlatar belakang guru matematika mengimplementasikan lesson study melalui kegiatan workshop sebagai latihan penerapan dan penilaian langsung kemampuan guru mengajar. Dengan lesson study berbasis STEM diharapkan guru dapat melakukan diskusi dalam merencanakan pembelajaran, melaksanakan pengamatan guru model dalam mengajar dan dapat melakukan refleksi pembelajaran. Penelitian menggunakan penelitian tindakan sekolah berdasarkan Kemmis \& taggart yang terdiri dari 2 siklus yang diawali dengan perencanaan, tindakan, observasi dan refleksi. Sebagai subyek penelitian adalah guru SMK Negeri 1 Singkep yang terdiri dari 28 guru. Dari hasil penelitian ini, ditemukan bahwa melalui penerapan metode ini, (1) guru 
dapat meningkatkan kemampuan mengajar berbasis STEM, (2) guru dapat meningkatkan keterampilan dalam melakukan observasi, dan (3) guru dapat meningkatkan pengetahuan dalam hal menambah wawasan metode pembelajaran di kelas . Berdasarkan hasil analisis data, menunjukkan bahwa metode ini efektif untuk meningkatkan kemampuan mengajar guru berbasis STEM, pada siklus I rata-rata kemampuan guru 70.82 dan meningkat menjadi 78.88 pada siklus II, sehinga terjadi kenaikan 8.06 yang cukup berarti.

Kata kunci : studi pelajaran; Batang; Matematika;

\section{Pendahuluan}

Menurut Ki Hajar Dewantoro, pendidikan yaitu tuntutan didalam hidup tumbuhnya anak-anak, adapun maksudnya pendidikan yaitu menuntun segala kekuatan kodrat yang ada pada anak-anak itu, agar mereka sebagai manusia dan sebagai anggota dapatlah mencapai keselamatan dan kebahagian setingi-tingginya (Megawati \& Sari, 2012).

Pendidikan sebagai sebuah kegiatan dan proses aktivitas yang disengaja merupakan gejala masyarakat ketika sudah mulai disadari pentingnya untuk membentuk, mengarahkan dan mengatur manusia sebagaimana dicita-citakan masyarakat (Gunawan, 2012).

Salah satu prinsip pendidikan sebagai proses pembudayaan dan pemberdayaan peserta didik yang berlangsung sepanjang hayat. Dalam proses tersebut diperlukan guru yang memberikan keteladanan, membangun kemauan, dan mengembangkan potensi dan kreativitas peserta didik (Sary, 2018).

Istilah Industri 4.0 lahir dari ide revolusi industri ke empat. European Parliamentary Research Service dalam Davies (2015) menyampaikan bahwa revolusi industri terjadi empat kali. Revolusi industri pertama terjadi di Inggris pada tahun 1784 di mana penemuan mesin uap dan mekanisasi mulai menggantikan pekerjaan manusia. Revolusi yang kedua terjadi pada akhir abad ke - 19 dimana mesin-mesin produksi yang ditenagai oleh listrik digunakan untuk kegiatan produksi secara masal. Penggunaan teknologi komputer untuk otomasi manufaktur mulai tahun 1970 menjadi tanda revolusi industri ketiga (Prasetyo \& Sutopo, 2018).

Industri 4.0 merupakan fenomena yang unik jika dibandingkan dengan tiga revolusi industri yang mendahuluinya. Industri 4.0 diumumkan secara apriori karena peristiwa nyatanya belum terjadi dan masih dalam bentuk gagasan (Drath \& Horch, 2014).

Ekonomi global saat ini sedang pada titik puncak perubahan besar yang sebanding besarnya dengan munculnya revolusi industri pertama atau perkembangan perakitan produksi, atau bahkan penemuan mikrocip. Kemajuan teknologi memungkinkan terjadinya otomatisasi hampir disemua bidang. Sementara itu, kepemilikan perangkat pintar di berbagaibagian dunia mengarah padatingkat keterkaitan satu sama yang lain yang tak terbayangkan sebelumnya. Diantara berbagai tantanganyang sedang 
dihadapidunia saat ini, mungkin yang palingbesaradalah bagaimanamembentukRevolusi Industrikeempat(disebut juga sebagai Industri 4.0) (Tjandrawinata, 2016).

Implikasi dari prinsip ini adalah pergeseran paradigma proses pendidikan, yaitu dari paradigma pengajaran ke paradigma pembelajaran. Pembelajaran adalah proses interaksi peserta didik dengan guru dan sumber belajar pada suatu lingkungan belajar. Proses pembelajaran perlu direncanakan, dilaksanakan, dinilai, dan diawasi agar terlaksana secara efektif dan efisien. Terlebih dengan tantangan zaman menuju era revolusi industry 4.0. diperlukan bekal pengetahuan dan keterampilan yang cukup pada peserta didik (Jayawardana, 2017).

Industri 4.0 adalah sebuah istilah yang diciptakan pertama kali di Jerman pada tahun 2011 yang ditandai dengan revolusi digital. Industri ini merupakan suatu proses industri yang terhubung secara digital yang mencakup berbagai jenis teknologi, mulai dari 3D printing hingga robotik yang diyakini mampu meningkatkan produktivitas (Satya, 2018).

Komponen yang paling penting dalam dunia pendidikan adalah kurikulum. Menurut (Hamalik, 2012) kurikulum adalah seperangkat rencana dan pengaturan mengenai isi dan bahan pelajaran serta cara yang digunakan sebagai pedoman penyelenggaraan kegiatan belajar mengajar di dalam kelas. Kurikulum dijadikan sebagai sebuah wadah yang akan menentukan arah pendidikan sehingga berhasil atau tidaknya sebuah pendidikan sangat bergantung pada kurikulum yang digunakan. Pada Tahun Ajaran 2013/2014, Indonesia menerapkan kurikulum baru yang dikenal dengan sebutan kurikulum 2013 (Dewi, Adnyani, \& Mardani, 2019).

Mengingat kebhinekaan budaya, keragaman latar belakang dan karakteristik peserta didik, serta tuntutan untuk menghasilkan lulusan yang bermutu, proses pembelajaran untuk setiap mata pelajaran harus fleksibel, bervariasi, dan memenuhi standar. Proses pembelajaran pada setiap satuan pendidikan dasar dan menengah harus interaktif, inspiratif, menyenangkan, menantang, dan memotivasi peserta didik untuk berpartisipasi aktif, serta memberikan ruang yang cukup bagi prakarsa, kreativitas, dan kemandirian sesuai dengan bakat, minat, dan perkembangan fisik serta psikologis peserta didik.

Dari hasil pengamatan dan supervisi peneliti selaku kepala SMK Negeri 1 Singkep ditemukan sekitar 82,35\% guru dari 28 orang guru yang ada melaksanakan pembelajaran dengan metode pembelajaran yang kurang bervariatif. Kebiasaan yang terjadi pada guru yaitu tidak menghubungkan pengetahuan yang sebelumnya dengan materi yang akan disampaikan. Guru tidak melakukan apersepsi secara tepat. Dalam hal pembelajaran guru jarang mengkaitkan dengan kehidupan sehari-hari sehingga motivasi siswa dalam belajar masih kurang. Terlebih guru kurang menumbuhkan berfikir kritis, komunikasi, kerjasama dan kreativitas siswa sebagai tuntutan era revolusi industry 4,0 (Perwitasari, 2015).

Dari hasil pengamatan peneliti kurang bervariasinya guru dalam pembelajaran disebabkan oleh beberapa hal, antara lain : (1) minimnya pengetahuan guru dalam metode atau model pembelajaran khususnya berbasis STEM, (2) motivasi guru yang 
rendah untuk meningkatkan profesionalnya sebagai guru, (3) kurangnya pelatihan bagi guru dalam kemampuan mengelola proses pembelajaran, (4) kurangnya minat, prakarsa dan kreativitas guru dalam pembelajaran (Mandasari, 2018).

Dari identifikasi permasalahan yang berkaitan dengan kondisi guru-guru SMK Negeri 1 Singkep, maka peneliti selaku Kepala Sekolah merencanakan tindakan yang strategis pembudayaan Lesson Study di kalangan guru. Pembudayaan lesson study ini disejalankan dengan pelaksanaan penelitian tindakan sekolah (PTS) yang berjudul: “ Membumikan Lesson Study dalam Meningkatkan Kemampuan Mengajar Berbasis STEM Bagi Guru SMK Negeri 1 Singkep Kabupaten Lingga. Tujuan dari penelitian ini adalah Untuk menemukan prosedur yang efektif dalam menerapkan lesson study dalam meningkatkan kemampuan mengajar berbasis STEM bagi guru SMK Negeri 1 Singkep. Dan manfaatnya untuk mengembangkan konsep kualitas pembelajaran dan lesson study di dunia pendidikan dan sebagai landasan untuk penelitian tindakan selanjutnya.

\section{Metode Penelitian}

Penelitian ini menggunakan metode penelitian tindakan yang difokuskan pada situasi sekolah, yang disebut action research (S. Kemmis \& McTaggart, 1988). Subjek penelitian ini adalah secara umum seluruh guru pada SMK Negeri 1 Singkep yang terdiri atas 28 guru diantaranya 3 guru matematika sebagai fokus bimbingan peneliti. Penelitian ini bertujuan untuk menerapkan lesson study sebagai upaya untuk meningkatkan kemampuan mengajar berbasis STEM bagi guru SMK Negeri 1 Singkep pada semester genap tahun pelajaran 2018/2019. Desain penelitian ini mengacu kepada model (Kemmis, McTaggart, \& Nixon, 2013) yang terdiri dari 4 (empat) komponen yaitu perencanaan, tindakan, pengamatan (observasi), dan refleksi.

Teknik pengumpulan data yang digunakan dalam penelitian ini adalah : dokumentasi dan observasi. Analisis data dalam penelitian ini dilakukan selama dan setelah pengumpulan data. Indikator keberhasilan yang menjadi kriteria pengambilan keputusan adalah penilitian tindakan sekolah dititikberatkan pada aspek hasil penilaian kemampuan guru dalam mengajar dimana $75 \%$ guru mendapat nilai minimal 75 dan rata-rata penilain 75 .

\section{Hasil dan Pembahasan}

\section{Kondisi Awal}

Melalui komunikasi kolaborasi pada awal pertemuan guru-guru, permasalahan mulai terdengar dari keluhan guru dalam melaksanakan pembelajaran melalui lesson study dan pembelajaran berbasis STEM. Tentu saja hal tersebut bukan masalah yang mudah, sehingga perlu mencarikan solusi terbaik untuk mengatasinya, supaya dapat meningkatkan minat dan kemampuan guru untuk melakukan pembelajaran melalui lesson study dan pembelajaran berbsis STEM. Melalui Lesson Study akhirnya beberapa permasalahan pembelajaran berbasis STEM dapat diperbaiki , yaitu: (1) Rendahnya kemampuan guru dalam pembelajaran, (2) rendahnya kualitas guru 
dalam merencanakan pembelajaran, (3) Kurangnya kualitas guru dalam menggunakan media pembelajaran, dan (4) Rendahnya minat guru untuk memperbaiki pembelajaran.

Permasalahan di atas, kemudian dianalisis secara kolaboratif berdasarkan observasi dan pengamatan dan hasil pembinaan di lapangan. Hal tersebut, dilakukan untuk mencari dan menentukan penyebab yang paling mungkin dilakukan, kemudian bagaimana peran kepala sekolah bisa menemukan permasalahan yang berkaitan dengan rendahnya kemampuan guru dalam pembelajaran berbasis STEM . Melalui tindakan pola pembinaan Lesson Study kepala sekolah sebagai peneliti bisa memberikan treatment lain seperti dengan bentuk pertanyaan, penjelasan, pemberian contoh, dan praktek. Dengan terus mendorong, memberi semangat kepada guru-guru di sekolah untuk melakukan perbaikan pembelajaran melalui lesson study agar bisa dianggap bermanfaat, mudah, dan menarik.

\section{Pelaksanaan Siklus I}

Pertemuan pada siklus ini sebanyak 2 kali tindakan berupa pertemuan untuk kegiatan workshop lesson study berbasis STEM pada tanggal 5 Januari dan 12 Januari 2019 sedangkan kegiatan penilaian kemampuan mengajar dilaksanakan pada tanggal 21 Januari sampai dengan 8 Februari 2019

a) Perencanaan Kegiatan

Pada tahap perencanaan ini, dilakukan kegiatan (1) menyusun rencana tindakan, (2) menyusun Lembar observasi khusus pelaksanan lesson study, (3) menyusun lembar penilaian kemampuan mengajar

b) Tindakan

Dalam penelitian ini menggunakan 2 bentuk tindakan yaitu workshop lesson study berbasis STEM dan penilaian kemampuan mengajar.

Tindakan 1 dilaksanakan berupa pelaksanaan workshop lesson study berbasis STEM. Tindakan dalam pelaksanaan workshop lesson study adalah: (a) Peneliti melaksanakan bimbingan teknis lesson study untuk menyamakan presepsi tentang : (1) tujuan lesson study, (2) manfaat lesson Study, (3) prosedur pelaksanaan lesson study melalui workshop, (b) praktik lesson study, (c) tanyajawab hasil praktik lesson study; (d) merefleksikan hasil praktik melalui presentasi yang ditanggapi oleh teman sejawat secara individu, (e) merencanakan tindak lanjut.

Teknik Praktik lesson study berbasis STEM : (a) Dikelompokkan menjadi kelompok kecil berdasarkan kelompok mata pelajaran atau rumpun. (b) Setiap kelompok berdiskusi membuat rencana pelaksanaan pembelajaran berbasis STEM yang akan ditampilakan, (c) Dari masing-masing kelompok diputuskan ada yang menjadi pengajar dan ada yang menjadi observer. observer tidak diperbolehkan mengganggu tetapi harus mencatat apa yang terjadi saat pembelajaran berlangsung. Observer diperbolehkan bergerak membantu pembelajaran bila diperlukan oleh pengajar, (e) Setelah melaksanakan pembelajaran di kelas setiap kelompok berdiskusi kembali untuk melakukan refleksi guna perbaikan 
pembelajaran, (f) Menyimpulkan dan membuat solusi bersama dari kejadian saat simulasi sebagai gambaran untuk mengatasi masalah pembelajaran

Tindakan 2 yaitu melaksanakan penilaian kemampuan mengajar guru, Aspek yang dinilai meliputi : 1. Kesiapan Alat dan Bahan 2. Motivasi dan Apersepsi 3. Menuliskan/ Menyampaikan KD/ Indikator 4. Menyampaikan materi dengan metoda yang bervariasi 5. Peran guru sebagai fasilitator 6 . Mengembangkan keterampilan siswa 7. Berkomunikasi lisan/ tulis dengan menggunakan bahasa yang baik dan benar 8. Menghubungkan maateri pembelaran dengan kehidupan sehari-hari/ teknologi/ lingkungan/ budi pekerti dsb 9. Menggunakan alat 10. Mengambil keputusan / menarik kesimpulan 11. Menggunakan teknik bertanya 12. Sikap dan minat siswa dalam pembelajaran 13. Memudahkan siswa berinteraksi dengan sarana pembelajaran 14. Memudahkan siswa bergerak (mobilitas) 15. Interaksi siswa dengan guru 16 Interaksi siswa dengan siswa lain (antar siswa) 17. Penilaian Proses. 18 Menyampaikan kompetensi yang dicapai 19. Memeberikan penilaian kognitif, afektif, dan psikomotor.20 Memberikan tugas mandiri untuk pertemuan berikutnya

c. Pengamatan siklus I

Hasil Penganatan sebagai berikut: (1) Pada pelaksanaan Workshop lesson study berbasis STEM guru nampak antusias dalam mengikuti lesson study. Dari 28 guru yang ada hanya ada 2 guru yang tidak hadir karena ijin keluarga. Dalam praktik pelaksanaan lesson study dari tingkat perencanaan sebagian besar guru termotivasi untuk menyampaikan pendapatnya dalam menyusun RPP berbasis STEM bersama, namun masih saling tunjuk untuk menjadi guru model. Dalam pelaksanaan pembelajaran di kelas guru model telah melaksanakan pembelajaran sesuai dengan RPP. Guru lain sebagai tim pengamat menulis hasil pengamatannya pada lembar observasi namun ada 8 guru yang belum mengisi lembar observasi secara sempurna. Dari kegiatan refleksi sebagian besar guru aktif memberi masukan, namun dari 3 guru matematika 1 orang guru matematika masih kurang aktif dalam memberikan masukan. (2) Pada kegiatan penilaian pembelajaran dengan pola lesson study, sebelum melaksanakan kegiatan pembelajaran semua guru menyusun RPP. (3) Masih terdapat 1 guru matematika yang belum dapat menyusun RPP berbasis STEM, (4) Pada umumnya guru dapat menyusun RPP sesuai dengan baik namun 1 guru matematika masih kurang.

Berikut nilai per indikator kemampuan guru dalam mengajar

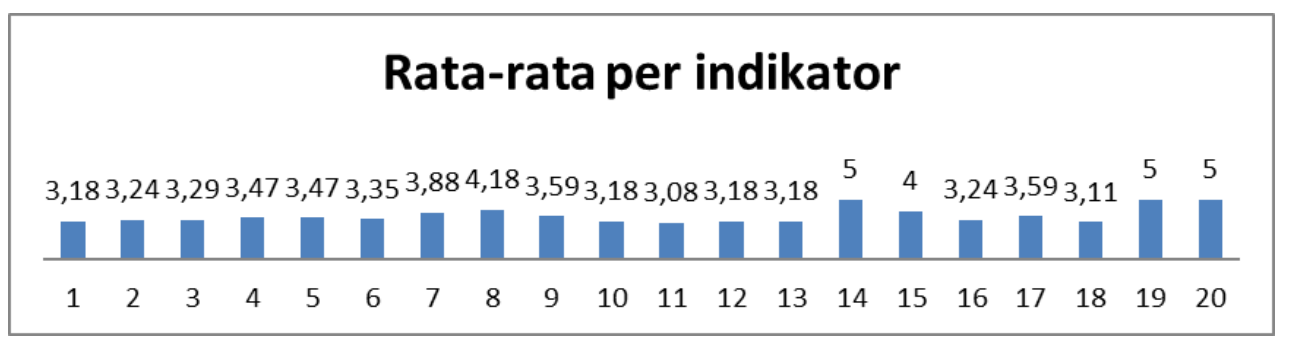

Grafik 1 Rata-rata Per Indikator Kemampuan Guru Dalam Mengajar siklus I 
Berdasarkan hasil pengamatan kolabolator terhadap kemampuan guru mengajar pada kegiatan pembelajaran yang memperoleh skor $\mathrm{C}$ terdapat $17.64 \%$ atau 3 orang guru yang masih perlu ditingkatkan kemampuan mengajarnya dan yang mendapatkan minimal kategori B (baik) adalah $82.36 \%$, sedangkan nilai rata-rata kemampuan guru dalam mengajar 70.82. Dari 3 orang gru matematika 2 orang guru matematika sudah bernilai baik dan 1 guru bernilai cukup.Hal ini belum mencapai indikator keberhasilan dalam penelitian ini, dengan demikian kemampuan guru mengajar pada pembelajaran pada Siklus 1 dinyatakan masih kurang dan masih perlu ditingkatkan. Hal ini karena kepala sekolah belum maksimal dalam melakukan pembinaan individu secara khusus dalam membuat RPP secara efektif dan pelasanaan pembelajaran di kelas pada saat lesson study berlangsung.

d. Refleksi Siklus 1

Dari hasil pengamatan diperleh data bahwa $72.28 \%$ guru yang mendapat nilai lebih dari 70, hal ini menunjukkan masih belum mencapai kriteria keberhasilan, sehingga perlu: (1) Diupayakan bimbingan dan perhatian yang sungguh-sungguh terhadap guru yang belum dapat membuat RPP berbasis STEM dengan baik, (2) Membimbing guru yang masih RPP belum sistematis, (3) Untuk peningkatkan kemampuan guru dalam membuat RPP, dilakukan pembinaan secara intensif dan berkelanjutan serta diskusi reflektif melalui lesson study, (4) Meningkatkan kemampuan guru dalam menyusun RPP berbsis STEM dan melaksanakan pembelajaran di kelas melalui bimbingan, arahan, kordinasi dan penguatan reflesi melalui lesson study.

\section{Pelaksanaan Siklus II}

Pertemuan pada siklus ini sebanyak 2 kali tindakan berupa pertemuan untuk kegiatan workshop lesson study berbasis STEM lanjutan pada tanggal 9 Februari dan 16 Februari 2019 dan kegiatan penilaian kemampuan mengajar yang dilaksanakan pada tanggal 18 februari sampai 1 Maret 2019

a. Perencanaan

Pada tahap perencanaan siklus II ini dengan memperhatikan refleksi siklus I, dilakukan kegiatan (1) menyusun rencana tindakan, (2) menyusun Lembar observasi khusus pelaksanan lesson study berbasis STEM , (3) menyusun lembar penilaian kemampuan mengajar

b. Tindakan Siklus II

Tindakan pada siklus II memusatkan pada kegiatan pembelajaran yang dilakukan oleh guru dan siswa dengan melakukan perbaikan kegiatan lesson study berbasis STEM ,mengamati merumuskan TPK, menyusun KBM, mengalokasikan waktu, menentukan bahan pengajaran, menentukan media belajar, membuka pelajaran, menjelasakan, menerapkan metode, mengajukan pertanyaan, menggunakan media belajar, mengadakan variasi, memberi penguatan, membimbing diskusi, memberi layanan individual, mengelola kelas, melaksanakan penilaian proses, melaksanakan penilaian akhir. Peneliti bersama 
kolaborator memberikan pertanyaan kepada guru berkaitan dengan kegiatan pembelajaran. Dan memberikan pembinaan individu kepada guru yang masih memiliki kemampuan kurang.

c. Pengamatan siklus II

Hasil pengamatan: (1) Pada pelaksanaan Workshop lesson study II guru nampak antusias dalam mengikuti lesson study. Dari 28 guru yang ada semua hadir dalam mengikuti workshop lesson study berbasis STEM. Dalam praktik pelaksanaan lesson study dari tingkat perencanaan sebagian besar guru termotivasi untuk menyampaikan pendapatnya dalam menyusun RPP berbasis STEM bersama, dan guru antusias untuk menjadi guru model termasuk 3 guru matematika. Dalam pelaksanaan pembelajaran di kelas guru model telah melaksanakan pembelajaran sesuai dengan RPP. Guru lain sebagai tim pengamat menulis hasil pengamatannya pada lembar observasi dan semua guru telah mengisi lembar observasi secara sempurna. Dari kegiatan refleksi sebagian besar guru aktif memberi masukan namun 3 guru masih kurang aktif dalam memberikan masukan. Dari pengamatan penelti 3 orang guru matematika telah aktif dalam memberikan masukan (2) Semua guru yang berjumlah 28 orang membuat RPP, untuk persiapan penilaian kemampuan mengajar termasuk 3 orang guru matematika, (3) Semua guru hadir dapat melaksanakan pembelajaran sesuai dengan jadwal yang telah ditentukan. (4) Pada umumnya guru dapat melaksanakan kegiatan pembelajaran dengan lancer. Berikut rata-rata perindikator kemampuan guru alam mengajar.

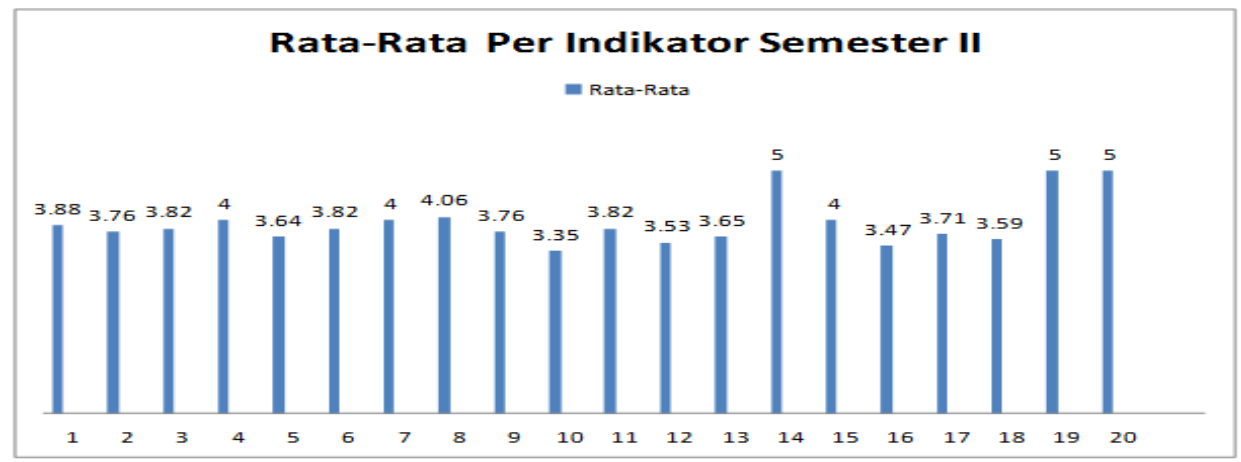

Grafik 2 Rata-rata Per Indikator Kemampuan Guru Dalam Mengajar Siklus II

\section{d. Refleksi Siklus II}

Berdasarkan hasil pengamatan kolabolator terhadap Aktivitas Guru Dalam PBM, diperoleh rata-rata nilai kemampuan guru dalam mengajar 78.88, dan yang memperoleh nilai C sebesar 5.88\% selebihnya B dan A sebesar 94.12\%, hal ini telah mencapai indikator keberhasilan dalam penelitian ini. Dari 3 guru matematematika kemampuan mengajar berbasis STEM 2 orang kategori A dan 1 orang kategori B. 


\section{Pembahasan Hasil Temuan Penelitian}

Berdasarkan hasil penelitian tindakan rata-rata penilaian kemampuan guru mengajar pada peroses belajar mengajar pada siklus I sebesar 70.82 dan meningkat 78.88 pada siklus II, Skor maksimum yang harus dicapai guru adalah 100 sehingga terdapat kenaikan 8.06. Dari hasil temuan penelitian tersebut, dalam upaya untuk meningkatkan kemampuan guru mengajar perlu dilakukan pembinaan yang intensif dan terkordinasi oleh kepala sekolah terhadap guru melalui penerapan lesson study berbasis STEM dan bimbingan individu secara berkelanjutan sehingga terbukti terjadi peningkatan kualitas pembelajaran pada guru SMK Negeri 1 Singkep. Hal ini sesuai dengan pendapat Caterine Lewis mengemukakan bahwa Lesson Study sangat efektif bagi guru karena telah memberikan keuntungan dan kesempatan kepada para guru untuk dapat: (1) memikirkan secara lebih teliti lagi tentang tujuan, materi tertentu yang akan dibelajarkan kepada siswa, (2) memikirkan secara mendalam tentang tujuan-tujuan pembelajaran untuk kepentingan masa depan siswa, misalnya tentang arti penting sebuah persahabatan, pengembangan perspektif dan cara berfikir siswa, serta kegandrungan siswa terhadap ilmu pengetahuan, (3) mengkaji tentang hal-hal terbaik yang dapat digunakan dalam pembelajaran melalui belajar dari para guru lain (peserta atau partisipan Lesson Study), (4) belajar tentang isi atau materi pelajaran dari guru lain sehingga dapat menambah pengetahuan tentang apa yang harus diberikan kepada siswa, (5) mengembangkan keahlian dalam mengajar, baik pada saat merencanakan pembelajaran maupun selama berlangsungnya kegiatan pembelajaran, (6) membangun kemampuan melalui pembelajaran kolegial, dalam arti para guru bisa saling belajar tentang apa-apa yang dirasakan masih kurang, baik tentang pengetahuan maupun keterampilannya dalam membelajarkan siswa, dan (7) mengembangkan "The Eyes to See Students" (kodomo wo miru me), dalam arti dengan dihadirkannya para pengamat (obeserver), pengamatan tentang perilaku belajar siswa bisa semakin detail dan jelas. Dengan demikian penerapan lesson study di kalangan guru efektif untuk diterapkan dalam rangka meningkatkan kemampuan guru dalam mengajar.

\section{Kesimpulan}

Dari hasil temuan penelitian setelah dilakukan tindakan pembinaan lesson stutdy oleh kepala sekolah terhadap guru pada siklus I diperoleh nilai rata-rata 70.82 sedangkan pada siklus II terjadi peningkatan kemampuan guru dalam mengajar diperoleh nilai rata-rata 78.88 dengan demikian terjadi kenaikan sebesar 8.06. Dari bimbingan khusus peneliti terhadap 3 orang guru matematika yang berkolaborasi dalam lesson study berbasis STEm terjadi peningkatan kualitas kemampuan mengajar berbasis STEM. Oleh karena itu lesson study efektif dilakukan untuk meningkatkan kemampuan guru mengajar secara intensif, bimbingan individu dan terkordinasi oleh kepala sekolah terhadap guru dalam praktek pembelajaran di kelas. 
Membumikan Lesson Study dalam meningkatkan kemampuan mengajar berbasis STEM bagi guru matematika SMK Negeri 1 Singkep Kabupaten Lingga

\section{BIBLIOGRAFI}

Dewi, Komang Ayu Kharisma, Adnyani, Kadek Eva Krishna, \& Mardani, Desak Made Sri. (2019). Implementasi Penilaian Autentik oleh Guru Bahasa Jepang di Kelas X SMA Laboratorium Undiksha Singaraja. Jurnal Pendidikan Bahasa Jepang Undiksha, 5(2), 286-294.

Drath, Rainer, \& Horch, Alexander. (2014). Industrie 4.0: Hit or hype?[industry forum]. IEEE Industrial Electronics Magazine, 8(2), 56-58.

Gunawan, Heri. (2012). Pendidikan karakter. Bandung: Alfabeta.

Hamalik, Oemar. (2012). Proses belajar dan Pembelajaran. Jakarta: Bumi Aksara.

Jayawardana, H. B. A. (2017). Paradigma pembelajaran biologi di era digital. Jurnal Bioedukatika, 5(1), 12-17.

Kemmis, Stephen, McTaggart, Robin, \& Nixon, Rhonda. (2013). The action research planner: Doing critical participatory action research. Springer Science \& Business Media.

Mandasari, Winda Jayanti. (2018). Pengaruh Model Pembelajaran SQ3R (Survey, Question, Read, Recite, Review) Terhadap Hasil Belajar Siswa Padapembelajaran Terpadu Kelas IV SD Al-Azhar Iway Halim Bandar Lampung.

Megawati, Yolanda Dian Nur, \& Sari, Annisa Ratna. (2012). Model pembelajaran kooperatif tipe team assisted individualization (TAI) dalam meningkatkan keaktifan siswa dan hasil belajar akuntansi siswa kelas XI IPS 1 SMA Negeri 1 Banjarnegara Tahun Ajaran 2011/2012. Jurnal Pendidikan Akuntansi Indonesia, 10(1).

Perwitasari, Wahyu Renni. (2015). SMA Negeri 3 Bantul Alamat: Gaten, Trirenggo, Bantul, Yogyakarta Telepon (0274)-6993432.

Prasetyo, Hoedi, \& Sutopo, Wahyudi. (2018). Industri 4.0: Telaah Klasifikasi aspek dan arah perkembangan riset. J@ Ti Undip: Jurnal Teknik Industri, 13(1), 17-26.

S. Kemmis \& McTaggart, R. (1988). The action research planner. Victoria. Australia: Deakin University.

Sary, Yessy Nur Endah. (2018). Buku Mata Ajar Evaluasi Pendidikan. Deepublish.

Satya, Venti Eka. (2018). Strategi Indonesia Menghadapi Industri 4.0. Info Singkat, 10(9), 19-24.

Tjandrawinata, Raymond R. (2016). Industri 4.0: Revolusi industri abad ini dan pengaruhnya pada bidang kesehatan dan bioteknologi. Jurnal Medicinus, 29(1), 31-39. 